\title{
Effect of foliar fertilization of soluble fertilizer and times of sowing on the crop growth and yield of greengram in rainfed vertisols
}

\author{
S. Subbulakshmi \\ Agricultural Research Station, Kovilpatti (T.N.) India \\ (Email: subbuagri@rediffmail.com)
}

\begin{abstract}
The field experiments were conducted during 2011-12, 2012-13 and 2013-14 in Rabi season (October - January) at Agricultural Research station, Kovilpatti, Tamil Nadu to study the response of greengram to foliar fertilization and different times of sowing under rainfed situation. The results of the experiment revealed that sowing during $39^{\text {th }}$ standard week registered increased growth and yield parameters viz., DMP, LAI, number of pods/plant, pod length, number of seeds/pod which reflected on increased grain yield. Significantly lower grain yield was recorded by seeds sown in the $43^{\text {rd }}$ standard week. Similarly among the foliar spraying of different soluble ferilizer and biofertilizer tried, seed treatment with Rhizobium, PSB and Methylobaterium (600 g/ha each) and foliar application of Methylobaterium ( $2 \mathrm{ml} /$ lit) on 30 and 45 DAS $\left(\mathrm{F}_{7}\right)$ recorded significantly increased growth and yield attributes and yield of the crop which was followed by seed treatment with Rhizobium and PSB (600 g/ha each) $+2 \% \mathrm{KCL}+100$ ppm boric acid foliar spray on 30 and $45 \mathrm{DAS}\left(\mathrm{F}_{6}\right)$.
\end{abstract}

Key Words : Dates of sowing, Foliar fertilization, Greengram, Methylobacterium, Yield

View Point Article : Subbulakshmi, S. (2019). Effect of foliar fertilization of soluble fertilizer and times of sowing on the crop growth and yield of greengram in rainfed vertisols. Internat. J. agric. Sci., 15 (2) : 255-259, DOI:10.15740/HAS/IJAS/15.2/255-259. Copyright@2019: Hind Agri-Horticultural Society.

Article History : Received : 15.01.2019; Revised : 06.05.2019; Accepted : 13.05.2019 